\title{
E-Banking Practice in Bangladesh: Comparative Study on Male and Female Users
}

\author{
Mohammad Shamsus Sadekin ${ }^{1,}$, Md. Abdul Hannan Shaikh ${ }^{2}$ \\ ${ }^{1}$ Department of Humanities, Chittagong University of Engineering \& Technology, Chittagong, Bangladesh \\ ${ }^{2}$ Department of Management, Islamic University, Kushtia, Bangladesh \\ Email address: \\ sadekinmba@yahoo.com (M. S. Sadekin) \\ ${ }^{*}$ Corresponding author
}

\section{To cite this article:}

Mohammad Shamsus Sadekin, Md. Abdul Hannan Shaikh. E-Banking Practice in Bangladesh: Comparative Study on Male and Female Users. International Journal of Business and Economics Research. Vol. 5, No. 3, 2016, pp. 71-74. doi: 10.11648/j.ijber.20160503.16

Received: April 27, 2016; Accepted: May 6, 2016; Published: May 26, 2016

\begin{abstract}
E-banking implies provision of banking products and services through electronic delivery channels. Factors that affect e-banking practice and its security are different from traditional banking services because of their uncertain nature of the online environment. Every step in the online banking activities is secured by one or more security mechanisms. Most of the Bangladeshi customers both male and female are not conscious about e-banking security. They have lack of technical knowledge to handle their e-bank account. Many of them have no computer in their residence. Female users are more conscious than male. Bangladeshi banks are operating their e-banking functions by non-technical hand. The main objective of present study is to find out the perception, attitude and practice of male and female users of e-banking in Bangladesh. The investigation was concentrated on male and female users of e-banking in various divisions, districts, towns and rural areas in Bangladesh. The sample consisted of 22 female and 98 male bankers and bank customers, were selected purposively from various territory. Out of 120 respondents, 48 bankers and 72 bank customers gave their opinion on many issues of e-banking. Data was collected using questionnaire administrated by the researcher. Data were processed through micro computer using Statistical Package for Social Science (SPSS). For analyzing data suitable statistical tools such as chi-squire test and Pearson product correlation were used.
\end{abstract}

Keywords: Trust of E-Banking, Types of Password, Check the Bank Statement

\section{Introduction}

Electronic banking does not mean only 24- hours access to cash through an Automated Teller Machine (ATM) or Direct Deposit of pay checks into checking or savings accounts as many consumers may think. Electronic banking (e-banking) involves many different types of transactions; it is a form of banking where funds are transferred through an exchange of electronic signals between financial institution, rather than exchange of cash, cheques or other negotiable instruments [1]. The financial institutions are now compelled to be involved in ICT to cope with the changes in the modern business trend. As a third-world developing country, Bangladesh is far behind to reach the expected level in global banking system. So it is our urgent need to upgrade its banking system [2]. Electronic banking provides enormous benefits to consumers in terms of the ease and cost of transactions. But it also poses new challenges for country authorities in regulating and supervising the financial system and in designing and implementing macroeconomic policy [3]. At present information technology is a subject of widespread interest in Bangladesh. The government has declared IT as a trust sector and set up a vision of digital Bangladesh in 2021. But Bangladesh has long way to go in a very short time to enjoy the fruits of information age. It will be possible when there will be political commitment with better IT infrastructure, internal network, country domain and above all a high speed fiber optic link to the information superhighway [4]. Male behavior towards internet banking might be different to female' behavior. So banks should be aware of these differences and create different strategies to meet male and female requirements. Subjective norm was 
found to have significant effect on male behavior towards the usefulness and ease of use of internet banking, but it has no influence on their behavioral intention to utilize Internet banking. In case of female subjective norm has no influence on their perceptions and behavior towards the usefulness and ease of use of internet banking and no effect of their behavioral intention to use internet banking [5]. Banking is an activity that relies deeply on information technology to acquire, process, and deliver the information to all relevant customers. As a result Online Banking was introduced as a channel where bank customers could perform their financial transactions electronically via their banks' Web sites. [6]. Bangladeshi customers have very poor knowledge about ebanking transactions. They are not ready to accept any financial difficulties and will not trust on e-banking services. Bankers have to be sincere about e-banking security. Therefore e-banking may be secured by taking necessary initiatives, like using finger print, authentication of cash withdrawals, using close circuit camera, increasing internet speed, increasing awareness, using protective password and antivirus, formulation of e-banking supporting policies, close monitoring, legal provisions for controlling frauds etc. [7]. Some other study have done on the followings: e-banking practice [8], adoption of e-banking [9], e-business [10], ebanking-future banking [11]. But no comprehensive study was made on e-banking practice in Bangladesh; a comparative study between male and female users.

\section{Methodology}

The study has been done mainly based on primary sources of data. Samples of a total 120 were randomly selected of which 98 are male and 22 are female. Primary data has been collected from 76 customers and 48 bankers of 16 selected banks. Data was collected from Dhaka, Chittagong, Rajshahi, Khulna and Rangpur Divisions those offer e-banking facilities to their customers. e.g. i. Sonali Bank Ltd. ii. Janata Bank Ltd. iii. Rupali Bank Ltd. iv. BRAC Bank, v. DutchBangla Bank Ltd vi. Eastern Bank Ltd vii. IFIC Bank Ltd. viii. Islami Bank Bangladesh Ltd. ix. Mercantile Bank Ltd. x. Mutual Trust Bank Ltd. xi. One Bank Ltd. xii. Prime Bank Ltd. xiii. Pubali Bank Ltd. xiv. Social Islami Bank Ltd. xv. Standard Chartered Bank Ltd. xvi. HSBC. Bank customers were selected from university, college and school teachers and students, businessmen and other professionals from private and public sectors. The questionnaire was distributed directly to the respondents through e-mail. Researcher meet with some respondents and provide questionnaire directly. In some case researcher also take help from friends and relatives to collect data.

\section{Results and Analysis}

Table 1. Gender Wise Opinion About Security of E-banking in Bangladesh.

\begin{tabular}{|c|c|c|c|c|c|c|}
\hline \multirow[b]{2}{*}{ Sex } & \multicolumn{5}{|c|}{ Security of E-banking } & \multirow[b]{2}{*}{ Total No (\%) } \\
\hline & $\begin{array}{l}\text { Highly Secured } \\
\text { No. }(\%)\end{array}$ & $\begin{array}{l}\text { Sufficient Secured } \\
\text { No. }(\%)\end{array}$ & $\begin{array}{l}\text { Not Enough Secured } \\
\text { No. }(\%)\end{array}$ & $\begin{array}{l}\text { Not Secured At All } \\
\text { No. }(\%)\end{array}$ & $\begin{array}{l}\text { Don't Know } \\
\text { No. }(\%)\end{array}$ & \\
\hline \multirow{2}{*}{ Male } & 12 & 39 & 36 & 1 & 10 & 98 \\
\hline & (12.24) & $(39.80)$ & $(36.73)$ & $(1.02)$ & $(10.21)$ & (100) \\
\hline \multirow{2}{*}{ Female } & 6 & 11 & 2 & 0 & 3 & 22 \\
\hline & $(27.27)$ & $(50)$ & $(9.10)$ & (0) & (13.63) & (100) \\
\hline Total & 28 & 50 & 28 & 1 & 13 & 120 \\
\hline
\end{tabular}

Table 1 shows that among the male respondents 39.80\% said e-banking in Bangladesh is "sufficient secured" and 1.02\% said "not secured at all". Among the female respondents 50\% said e-banking in Bangladesh is "sufficient secured" and no respondents said e-banking in Bangladesh is "not secured at all".

Table 2. Type of Password Used by Male and Female Respondents.

\begin{tabular}{|c|c|c|c|c|c|c|}
\hline \multirow{2}{*}{ Sex } & \multicolumn{6}{|l|}{ Type of Password } \\
\hline & Number No. (\%) & Letter No. (\%) & Number \& Letter No. (\%) & Mixed No. (\%) & Not Applicable No. (\%) & Total \\
\hline \multirow{2}{*}{ Male } & 29 & 15 & 19 & 7 & 18 & 98 \\
\hline & $(29.59)$ & $(15.31)$ & (19.39) & $(7.14)$ & $(18.37)$ & $(100)$ \\
\hline \multirow{2}{*}{ Female } & 9 & 1 & 3 & 3 & 6 & 22 \\
\hline & $(40.91)$ & $(4.55)$ & (13.64) & (13.64) & $(27.28)$ & $(100)$ \\
\hline Total & 38 & 16 & 22 & 10 & 34 & 120 \\
\hline
\end{tabular}

Table 2 shows that among the respondents $29.59 \%$ use some number digit as their e-banking password and $7.14 \%$ use mixed password (digit, letter and symbol) for e-banking the respondents and $40.91 \%$ female respondents use some digit as their ebanking password and $4.55 \%$ use letter as their e-banking password. 
Table 3. Male's and Female's Trust on E-banking in Bangladesh.

\begin{tabular}{|c|c|c|c|c|c|c|}
\hline \multirow{2}{*}{ Sex } & \multicolumn{5}{|l|}{ Trust on E-banking } & \multirow{2}{*}{$\begin{array}{l}\text { Total No. } \\
(\%)\end{array}$} \\
\hline & Don’t Know No. (\%) & Less Than $50 \%$ No. $(\%)$ & More Than 50\% No. (\%) & More Than $75 \%$ No. (\%) & $100 \%$ No. (\%) & \\
\hline Male & $\begin{array}{l}13 \\
(13.27)\end{array}$ & $\begin{array}{l}13 \\
(13.26)\end{array}$ & $\begin{array}{l}22 \\
(22.45)\end{array}$ & $\begin{array}{l}33 \\
(33.67)\end{array}$ & $\begin{array}{l}17 \\
(17.35)\end{array}$ & $\begin{array}{l}98 \\
(100)\end{array}$ \\
\hline Female & $\begin{array}{l}2 \\
(9.10) \\
15\end{array}$ & $\begin{array}{l}1 \\
(4.55) \\
14\end{array}$ & $\begin{array}{l}10 \\
(45.45) \\
32\end{array}$ & $\begin{array}{l}6 \\
(27.27) \\
39\end{array}$ & $\begin{array}{l}3 \\
(13.64) \\
20\end{array}$ & $\begin{array}{l}22 \\
(100) \\
120\end{array}$ \\
\hline
\end{tabular}

Table 3 shows that $33.67 \%$ the male respondents keep "more than $75 \%$ " trust on e-banking in Bangladesh and $13.26 \%$ trust "less than 50\%" on e-banking in Bangladesh. Among the female respondents $45.45 \%$ keep their trust on e-banking in Bangladesh "more than 50\%" and 4.55\% trust "less than 50\%".

Table 4. Password Shared by the Male and Female Respondents.

\begin{tabular}{|c|c|c|c|c|}
\hline \multirow{2}{*}{ Sex } & \multicolumn{3}{|l|}{ Sharing Password } & \multirow{2}{*}{ Total } \\
\hline & Share Password No. (\%) & Don't Share Password No. (\%) & Not Applicable No. (\%) & \\
\hline Male & $\begin{array}{l}10 \\
(10.20)\end{array}$ & $\begin{array}{l}73 \\
(74.49)\end{array}$ & $\begin{array}{l}15 \\
(15.31)\end{array}$ & $\begin{array}{l}98 \\
(100)\end{array}$ \\
\hline Female & $\begin{array}{l}6 \\
(27.27)\end{array}$ & $\begin{array}{l}10 \\
(45.45)\end{array}$ & $\begin{array}{l}6 \\
(27.28)\end{array}$ & $\begin{array}{l}22 \\
100)\end{array}$ \\
\hline Total & 16 & 83 & 21 & 120 \\
\hline
\end{tabular}

Table 4 shows that among the male respondents the $74.49 \%$ do not share their e-banking password to others and $10.20 \%$ respondents share their password to others. Among the female respondents $45.45 \%$ do not share their e-banking password with others and $27.27 \%$ share their password with others.

Table 5. Person With Whom the Male and Female Account Holders Share Their Password.

\begin{tabular}{|c|c|c|c|c|c|c|}
\hline \multirow{2}{*}{ Sex } & \multicolumn{5}{|c|}{ Person to Whom The Respondents Share E-banking Password } & \multirow{2}{*}{ Total No. (\%) } \\
\hline & Wife No. (\%) & Husband No. (\%) & Parents No. (\%) & Other Family Members No. (\%) & Friends No. (\%) & \\
\hline Male & $\begin{array}{l}10 \\
(100)\end{array}$ & $\begin{array}{l}0 \\
(0)\end{array}$ & $\begin{array}{l}0 \\
(0)\end{array}$ & $\begin{array}{l}0 \\
(0)\end{array}$ & $\begin{array}{l}0 \\
(0)\end{array}$ & $\begin{array}{l}10 \\
(100)\end{array}$ \\
\hline Female & $\begin{array}{l}0 \\
(0)\end{array}$ & $\begin{array}{l}2 \\
(33.33)\end{array}$ & $\begin{array}{l}4 \\
(66.67)\end{array}$ & $\begin{array}{l}0 \\
(0)\end{array}$ & $\begin{array}{l}0 \\
(0)\end{array}$ & $\begin{array}{l}6 \\
(100)\end{array}$ \\
\hline Total & 10 & 2 & 4 & 0 & 0 & 16 \\
\hline
\end{tabular}

Table 5 shows that among the male respondents who share their password with other $100 \%$ of them share their password with their wife and female users who share their password among them $66.67 \%$ share with their parents and $33.33 \%$ share their password with their husband.

Table 6. Sign-out from Personal Account and Bank Web-site by Male and Female Users After Making any E-transaction.

\begin{tabular}{lllll}
\hline \multirow{2}{*}{ Sex } & Sign-out From Bank Account & & & Not Applicable No. (\%) \\
\cline { 2 - 4 } & Sign-Out No. (\%) & Don't Sign-Out No. (\%) & 15 & Total \\
\hline \multirow{2}{*}{ Male } & 47 & 36 & $(15.31)$ & $(100)$ \\
& $(47.96)$ & $(36.73)$ & 6 & 22 \\
Female & 11 & 5 & $(27.27)$ & $(100)$ \\
Total & $(50)$ & $(22.73)$ & 21 & 120 \\
\hline
\end{tabular}

Table 6 shows that among the male respondents 47.96\% sign-out from bank web-site after making any transaction and $36.73 \%$ do not sign-out from bank web-site. Out of 22, 50\% female respondents sign-out from bank web-site after making any transaction and $22.73 \%$ do not sign-out after completing any transaction.

Table 7. Time Duration of Checking Bank Statement by Male and Female Users.

\begin{tabular}{lllllllll}
\hline \multirow{2}{*}{ Sex } & \multicolumn{1}{l}{ Checking Bank Statement } & Weekly & Monthly & Yearly & Don't Check & Not Applicable & Other & Total \\
\cline { 2 - 8 } & Daily & 24 & 19 & 0 & 21 & 15 & 4 & 98 \\
Male & 15 & $(24.49)$ & $(19.39)$ & $(0)$ & $(21.43)$ & 15.31 & $(4.08)$ & $(100)$ \\
& $(15.31)$ & 7 & 04 & 0 & 3 & 6 & 0 & 22 \\
\multirow{2}{*}{ Female } & 2 & $(31.82)$ & $(18.19)$ & $(0)$ & $(13.64)$ & $(27.27)$ & $(0)$ & $(100)$ \\
\multirow{2}{*}{ Total } & $(9.10)$ & 14 & 40 & 0 & 24 & 21 & 4 & 120 \\
\hline
\end{tabular}


Table 7 shows that among the male respondents $34.49 \%$ check their e-bank statement "weekly" and $15.31 \%$ do not check their bank statement. Out of 22 female users $31.82 \%$ "monthly" check their e-bank statement and $27.27 \%$ do not check their e-bank statement.

\section{Findings}

i. E-banking Security is Sufficient: E-banking transactions are sufficient secured in Bangladesh. A big portion of male $(39.80 \%)$ and female (50\%) respondents said e-banking in Bangladesh is sufficient secured. (See Table 1)

ii. Customer use Some Digit as Their Password: It is revealed from Table 2 that majority male (29.59\%) and female $(40.21 \%)$ respondents use some number digit as their e-banking password.

iii. Male Users Trust E-banking More than Female: It is gained from Table 3 that majority male users (33.67\%) trust on e-banking "more than $75 \%$ " whereas majority female users trust on e-banking "more than 50\%".

iv. Female Users Share their E-banking Password More Than Male: It is found from Table 4 that female users $(27.27 \%)$ tendency of sharing password is more than male $(10.20 \%)$ users.

v. Accounts Holders Share Their E-banking Password With Their spouse and Relatives: The male users who share e-banking password $100 \%$ share it with their wife but the female users who share e-banking password majority of them $(66.67 \%)$ share it with their parents. (See. Table 5)

vi. Many Users Both Male and Female do not Sign-out from Bank Web-site after Completing any Transaction: It is gathered from Table 6 that $36.73 \%$ male and $22.73 \%$ female users do not sign-out from their account and bank web-site after doing any transaction.

vii. Many Account Holder s do not Check Their E-banking Statement: It is obtain from Table 7 that $21.43 \%$ male and $13.64 \%$ female users never check their e-bank statement.

\section{Conclusion}

E-Banking is a newly added concept in banking sector of Bangladesh but after starting it becoming popular in Bangladesh; thus almost all Bangladeshi banks offer many facilities of e-banking. Customers can withdraw and deposit money any time within 24 hours of a day. E-banking is growing in Bangladesh day by day. Domestic private commercial banks and foreign commercial banks are in leading position. State owned commercial banks do not offer all the functions of e-banking. Total population of Bangladesh is near equal proportion between male and female. As Bangladeshi female bank customers have limited knowledge on e-transactions and e-services so the authority of government has to encourage them to use e-banking. Bangladesh will be benefited immensely from e-banking if they can engage the whole bank account holders including male and female under e-banking system.

\section{References}

[1] Biswas S et. al., Electronic Banking in Bangladesh: Security Issues, Forms, Opportunities and Challenges. Canadian Journal on Scientific and Industrial Research. 2 (5), (2011).

[2] Islam M M (2005), "Proposed ICT Infrastructure for Ebanking in Bangladesh." Department of Computer and Systems Sciences, Royal Institute of Technology (KTH).

[3] Bahl S (2012), "E-Banking: Challenges \& Policy Implications.” International Journal of Computing \& Business Research.

[4] Al-Amin S and Rahman S (2010), "Application of Electronic Banking in Bangladesh: An Overview." Bangladesh Research Publication Journal. ISSN: 1998-2003, Volume-4, Issue: 2, Page 172-184.

[5] Ghamdi A (2011), "Gender Perceptions towards Internet Banking Loyalty: Empirical Evidence." Marketing. conference services.net/resources/.../ AM2011_0307.pd.

[6] Goyal V M \& Goyal G (2012), "Customer perception towards Internet banking w.r.f to private and foreign banks in India." International Journal of Computing \& Business Research.

[7] Sadekin M S and Shaikh M A H (2015), "Security of EBanking in Bangladesh." Journal of Finance and Accounting.

[8] Ali M M, Ahmed R, Rahman A, Azam M M (2007). "Electronic banking in Bangladesh: Potential and Constraints." Dhaka Uni. J. Mar. 10: 1-19.

[9] Hasan A H M S, Baten M A, Kamil A A and Parvin S (2010) "Adoption of E-Banking in Bangladesh: An exploratory Study." African Journal of Business Management. Vol. 4, No. 13.

[10] Ali M M (2010) "E-Business and Online Banking in Bangladesh: An Analysis.” AIUB Bus Econ Working Paper Series, No 2010-03.

[11] Hasan K (2007) "E-Banking in Bangladesh: The Future Banking.” www.wbiconpro.com/602-Kamril.pdf. 